\title{
Misconceivement About the Formation of True DeKalb Mounds in DeKalb County, Illinois
}

\author{
Michael Iannicelli ${ }^{1}$ \\ ${ }^{1}$ Independent Researcher \\ Correspondence: Michael Iannicelli, 710921 Ave Brooklyn, NY 11204, USA. Tel: 1-718-259-5574. E-mail: \\ michiann@optonline.net
}

Received: February 22, 2013 Accepted: March 21, 2013 Online Published: March 28, 2013

doi:10.5539/jgg.v5n2p31 URL: http://dx.doi.org/10.5539/jgg.v5n2p31

\begin{abstract}
A study is presented here in order to enhance knowledge about an earlier preliminary study of true DeKalb mounds. The DeKalb mounds of DeKalb County, IL are lowland, gigantic, oriented, low-relief, relict hillocks that are unquestionably a product of late Wisconsinan glacial deposition. However, a new controversy weighs them as being either a dead-ice moraine or ice-walled lake plains. The overall debate is based on the following generalities: aspects of the subglacial and supraglacial system; the relative physical geographic setting; sedimentology; paleontology; and isotope data. Specific, relevant issues include: the type of ice cover that existed over the mounds while being influenced by groundwater during their evolution; mound orientation being similar to the orientation of nearby, elevated moraines; superimposed mounds never appearing upon authentic ice walled lake plains; and the mound's highly dissimilar relief and shape to that of authentic ice-walled lake plains. Besides this study being a reproval concerning the identification of the lowland, gigantic, orientated DeKalb mounds as a dead-ice moraine, it also dismisses a counter-hypothesis of a glacial ice-walled lake origin for them.
\end{abstract}

Keywords: DeKalb mounds, late Wisconsinan, glacial dead ice, moraine

\section{Introduction}

A pragmatic controversy over the actual origin of the relict DeKalb mound landforms in north-central Illinois (Flemal, Hinckley, \& Hesler, 1973; Iannicelli, 2003; Curry et al., 2010) has recently been resurrected (Iannicelli, 2012; Curry et al., 2012). Modeling the development of these landforms is one way of understanding the origin (Iannicelli, 2003) (Figure 1) but very recent doubts raised about the modeling (Curry et al., 2012) now motivate this writer to provide both very detailed explanations about it and supplemental information relative to the mounds which will clear up confusion about the mounds.

\section{Area Description}

The DeKalb mounds of DeKalb County, IL are numerous late Wisconsinan hillocks within a vast till lowland as reported by Flemel et al. (1973) and Iannicelli (2003) (Figure 2). They occur in a cluster, while at face value they superficially resemble sediment-filled craters. Many mounds have one or more smaller ("satellite") mounds either superimposing or overlapping them. The heights of the overall mounds stand 1 to $5 \mathrm{~m}$ above the level of the surrounding till plain. Of specific concern in this report, are gigantic, NE-SW oriented mounds that measure from $400 \mathrm{~m}$ to $1.2 \mathrm{~km}$ in their longest dimension, reported by Flemel et al. (1973, p. 232) and Iannicelli (2003). The sedimentology of one gigantic, NE-SW oriented mound is illustrated in Figure 3 although this particular mound lacks a superimposed smaller (satellite) mound. The perimeter or margin of the mound is composed of a mass of pebbly sand belonging to the Tiskilwa Till Member of the Wedron Formation. The core of the mound is a lacustrine facies composed of finely laminated silt and clay with sporadic thin beds of sand. This is altogether overlain by a thin layer of gravel and sand that is capped by loess. The overlying thin layer of gravel and sand was post-depositionally deflated so that it became a lag prior to the arrival of loess (Flemal et al., 1973). Within the study areas of Flemel et al. (1973, Figure 1) or Iannicelli (2003, Figure 1), the mound field exists within an intermorainal lowland underlain by only a ground moraine of the Tiskilwa Till Member while being flanked to the immediate south by a higher-elevated morainic complex (late Wisconsinan Malden Till Member of the Wedron Formation) and farther to the north by a higher-elevated morainic complex (Tiskilwa Till member) 
(Lineback, 1979) (Figure 4). An obvious trend is that orientation of the gigantic mounds' long axes is parallel to the nearby, elevated NE-SW moraines (Flemal et al., 1973, p. 234; Iannicelli, 2003).
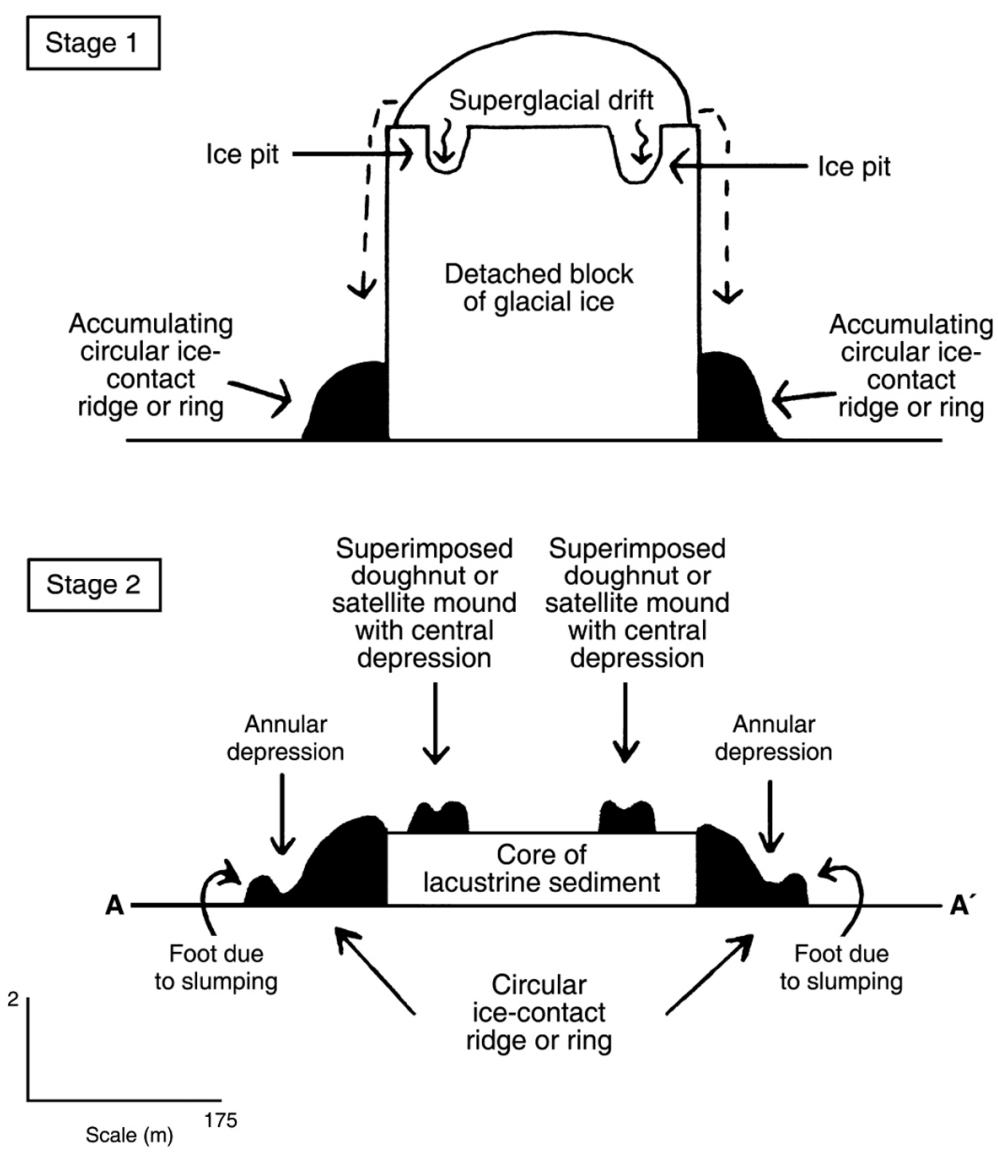

Figure 1. DeKalb mound development. Note A-A' (Figure 2). The contour of the basal lacustrine subsurface is not precisely known for this particular mound, so it's simplified here only as a plane. Speculatively, it most probably approaches the irregular contour of the basal lacustrine subsurface shown in Figure 3. Source:

Iannicelli (2003) 


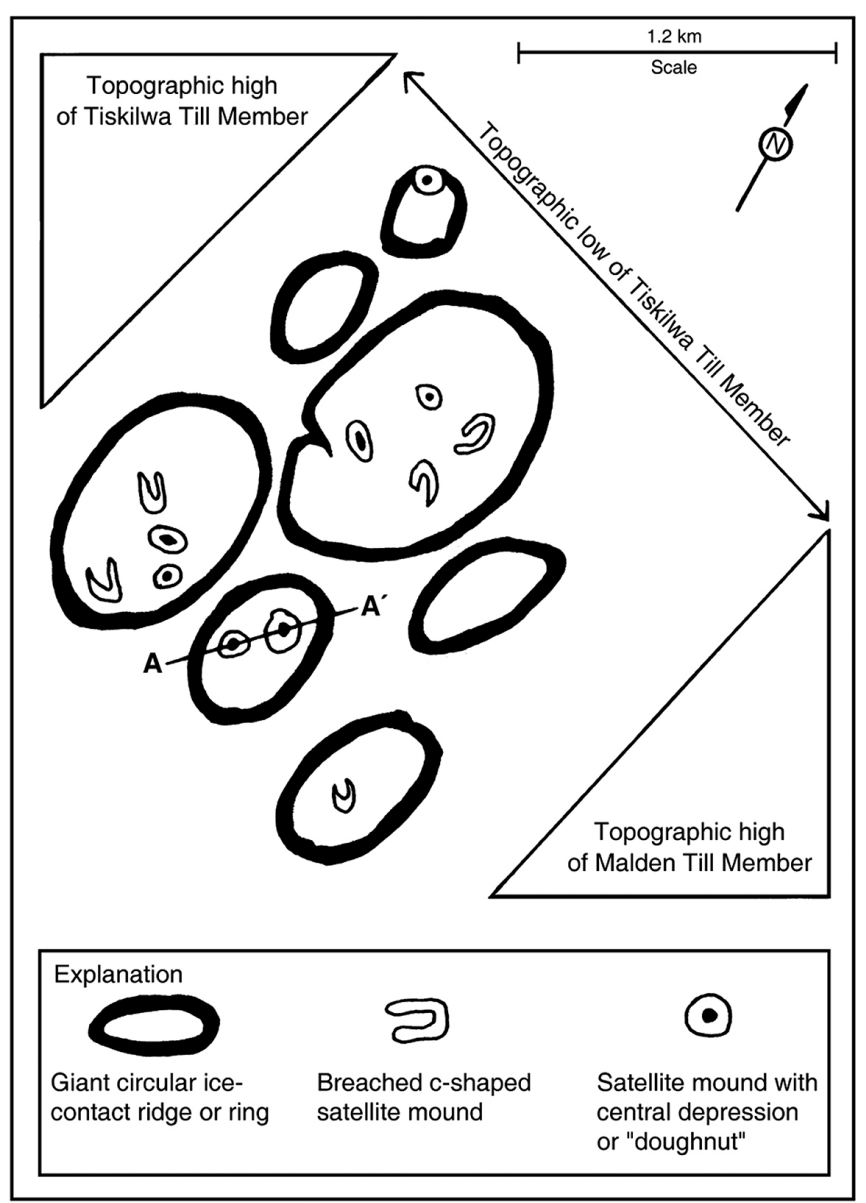

Figure 2. Sketch of an aerial photograph (Figure 7) showing lowland, gigantic, oriented DeKalb mounds located just east of DeKalb, IL. Note A-A' (Figure 1). Scale only applies to the mounds and not to the topographical highs and low of the till units. Source: Iannicelli (2003)

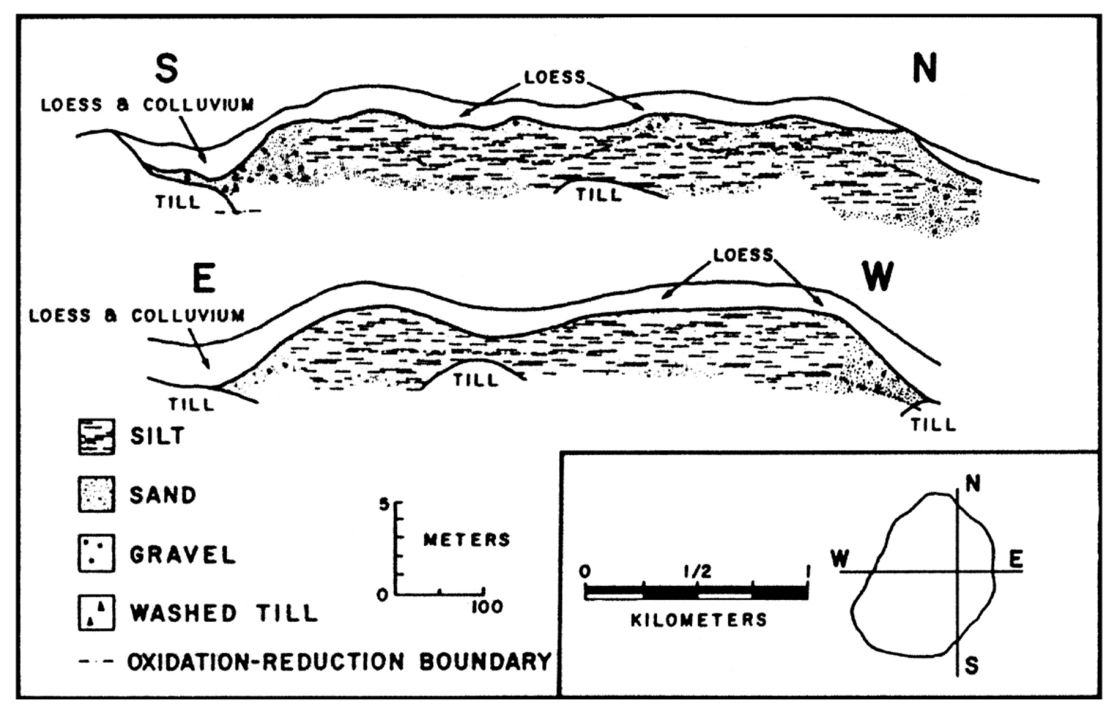

Figure 3. Cross-sections of a lowland, gigantic, oriented DeKalb mound showing the sedimentology. The stratigraphy includes sporadic, thin, beds of sand interstratified with the silt/clay of the lacustrine core. Note the wavy subsurface of the basal till. This particular mound lacks one or more of the typical, superimposed, smaller mounds. Source: Flemel et al. (1973) 


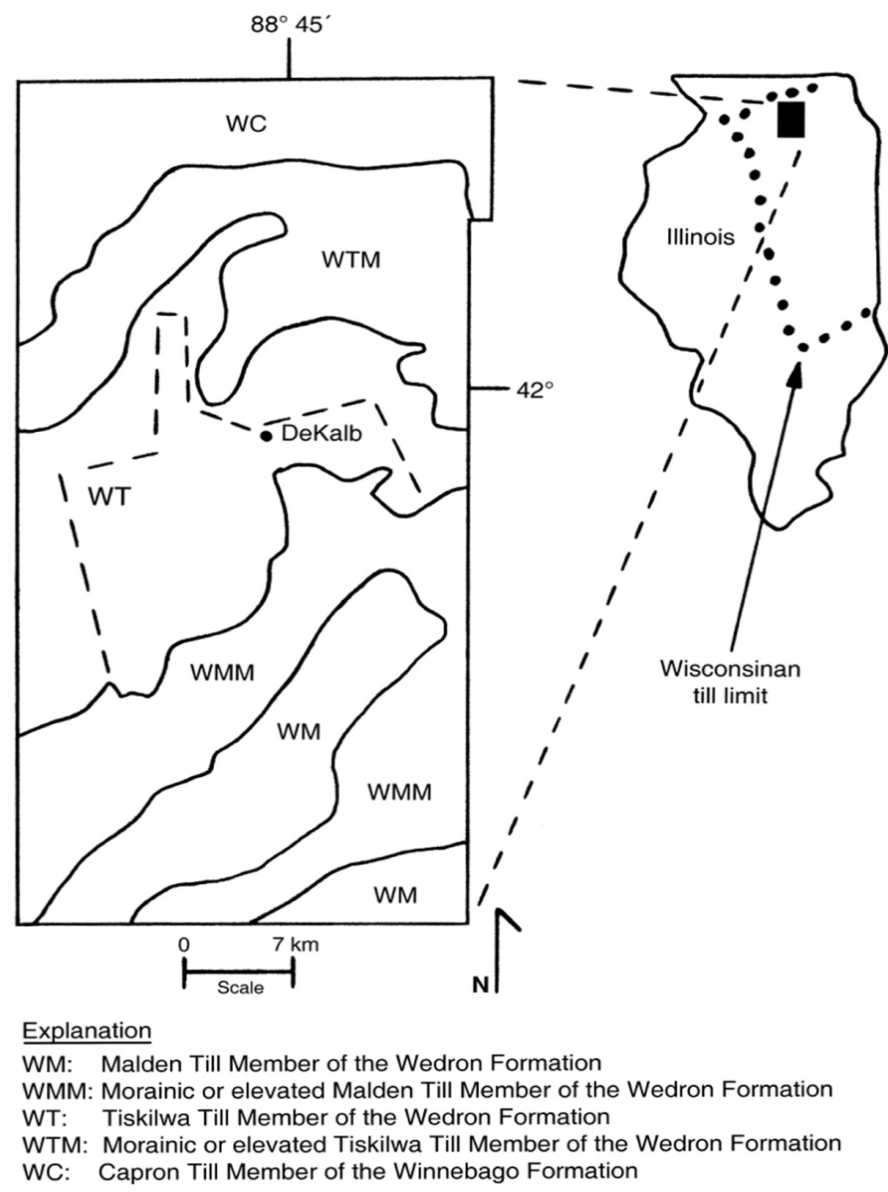

Figure 4. Surficial, geologic map of DeKalb County, IL showing the different till units of elevated moraines and lowland ground moraines. Limits of the gigantic, oriented DeKalb mounds are mostly just east, west and south of DeKalb, IL (within the dashed line symbol) while they only lie in the lowland of the Tiskilwa Till Member

(WT). A key observation here is that these mounds are parallel to the NE-SW orientation of the adjacent, elevated moraines. Source: Iannicelli (2003)

\section{Defending the Glacial Dead-Ice Model}

A glacial dead-ice origin for the DeKalb mounds was proposed by Bleuer (1974), Mickelson, Clayton, Fullerton and Borns (1983), Menzies and Shilts (1996, p. 113) and Iannicelli (2003). The model of DeKalb mound development (Figure 1) by Iannicelli (2003, Figure 7) is a near replica of a model used by Parizek (1969, Figure 5) for very similar, glacial dead-ice landforms in Canada. These identical models also follow the modeling of glacial dead-ice landforms (circular ice-contact/disintegration ridges; and hummocks or "doughnuts") in North Dakota, USA by Clayton (1967) or Clayton and Moran (1974). The particular argument here will focus on the study area of Flemal et al. (1973) and Iannicelli (2003) (Figure 4) which is incongruent with the study area of Curry, Konen and Larson (2008) and Curry et al. (2010) because of different elements between the two study areas. This will be discussed later in this report while addressing each doubt/question by Curry et al. (2012) concerning the dead-ice model of the DeKalb mounds' development (Figure 1).

\subsection{Development of a Subglacial Lacustrine Sediment Core}

The first question in Curry et al. (2012) is about how a subglacial debris lake forms within the model of Iannicelli (2003, Figure 7) (Figure 1). Firstly, Pleistocene subglacial lacustrine sediment accumulation is feasible and can occur because other Pleistocene subglacial lacustrine facies elsewhere were described by Brodzikowski \& van Loon (1991). The question of how this originates may be explained by the following sequence of events during the time of deglaciation. Initially, subglacial melting occurs beneath immobilized glacial ice when normal geothermal heat flux melts approximately $5 \mathrm{~mm}$ of basal ice annually (Cuffey \& Paterson, 2010, p. 110). A different, later process then occurs as seen in an analogy (Fleisher, 1986) who reported similar sediment deposition encompassed by enormous, very thick, stagnant ice blocks within dead-ice sinks (vast and very deep 
kettles), situated in a lowland setting located in New York. Two corings of this ice-contact sediment collected from within a dead-ice sink were illustrated by Fleisher (1986), one showed a 9 m-thick bed of silt and clay sandwiched between two beds of clean sand while the other coring showed a $36 \mathrm{~m}$-thick bed of silt and clay. The different sediment thicknesses between both corings were caused by subsidence and collapse after the very wide stagnant ice broke apart during progressive downwasting within the very wide dead-ice sink (Fleisher, 1986). He believed that the sediment deposition occurred over the ice block due to a low energy environment of low outwash braided streams during glacio-fluvial discharge (Figure 5). Conversely, model stratigraphic columns of Donjek-type and Scott-type braided outwash deposits display interstratified conglomeratic beds that range from 3 m-thick common cycle sequences to 60 m-thick uncommon cycle sequences (Miall, 1977). These are unlike Fleisher's (1986) two previously described corings. Thus, it is doubtful that braided stream low outwash deposited the New York non-conglomeratic thick sequential beds of sediment during downwasting. An alternate explanation for the production of the thick silt/clay bed would be a low-energy (paleo)environment only occurring within the stagnant ice itself during downwasting. This is because Fleisher (1986, p. 39) said that constant "growing space" or accommodation space for the sedimentation (silt/clay bed) was provided by the slowly melting ice block. It is reasonably asserted here that a subglacial or englacial cavity formed in the ice block which acted as a repository for the growing core of the glacio-lacustrine sediment within a dead-ice sink. Accomplishment of this could have been through late Wisconsinan active layer springs (within or upon the permafrost) discharging into the dead-ice sinks which also happen to occur in the basins of the DeKalb mounds while they were evolving as discussed by Flemel et al. (1973). Supporting this indication, Curry et al. (2008, p. 149) reported a kettle (Crystal Lake) just outside the study area (Crystal Lake, IL, 7.5' quadrangle) that was likely influenced more by the groundwater during its own genesis. A spring is very capable of carving a subglacial cavity within a stagnant ice block (Cuffey, personal comm., 2012) which would have allowed for the accumulation of glacio-lacustrine sediment. This is because the spring would have also transported suspended grains into the subglacial lake. Flemel et al. (1973, p. 237) recognized that the lacustrine core was derived from the adjacent and subjacent Tiskilwa Till Member. The physical geographic setting between the study areas of Fleisher (1986) and Iannicelli (2003) is similar because the basins that held the stagnant ice blocks all occurred within a topographic low. Stratigraphic relationships also are similar between the two study areas because Fleisher (1986) illustrated outwash surrounding the glacial ice blocks while Flemel et al. (1973, p. 238) observed that some mounds were found to be completely surrounded by outwash. Another similarity is the wavy basal contact of the glacial sediment underlying the silt/clay core within a DeKalb mound (Figure 3) matches the wavy basal contact of the drift underlying the silt/clay core within the dead-ice sink in Fleisher (1986, Figures 4 and 5). Lastly, another important observation of the analogous New York kettle landforms is that Fleisher (1986) also reported a hummocky surface upon the dead-ice sinks (Figure 5) that resulted during stagnant ice downwasting and the ceasement of glacio-fluvial discharge. Hummocky topography over dead-ice sinks or vast kettles has significant ramifications and will be discussed later in this study.

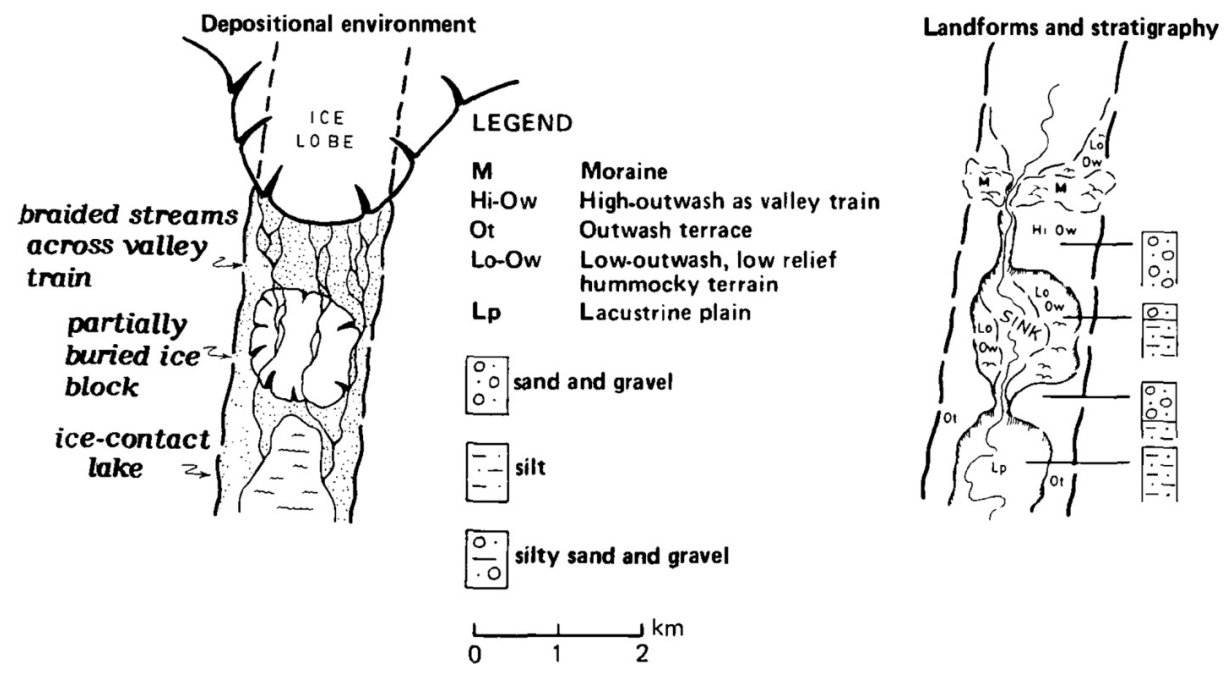

Figure 5. Bird's eye view of a dead-ice sink located in the New Berlin North, NY, 7.5' quadrangle. Area of "low-outwash" within the dead-ice sink includes hummocks on the surface and a buried, thick bed of silt/clay. Source: Fleisher (1986) 


\subsection{Development of Superimposed Satellite Mounds}

The next contention in Curry et al. (2012, p. 333) is the following statement: "if a lake should exist, then supraglacial sediment would fall into the lake, leaving no opportunity for sediment to collect within surficial ice pits (glacial karst) to eventually become superimposed glacial doughnuts (the small satellite mounds)". According to Brodzikowski and van Loon (1991, p. 262), supraglacial deposits are usually found overlying subglacial lacustrine facies in other formerly glaciated regions within the ice retreat zone. The previously mentioned doubt of Curry et al. (2012) is sequentially resolved by first noting that the sediment-filled ice pits are situated at the surface of a detached, ablating, glacial ice block (Iannicelli, 2003) (Figure 1). Aspects of the supraglacial system during deglaciation will now be discussed. Supraglacial ablation would be impeded because of supraglacial sediment insulating the underlying glacial ice (Fleisher, 1986; Benn \& Evans, 1998, p. 228). Hence, the supraglacial portion of the ice block is preserved through most of its disintegration history (Fleisher, 1986). Eventually, ablation triggers lateral spreading of the supraglacial sediment due to saturation (Benn \& Evans, 1998, p. 230; Iannicelli, 2003) while it slides over the sides of the ice block (Parizek, 1969; Iannicelli, 2003) (Figure 1). In the meantime, as previously discussed, the ablating, ice block would have sheltered a growing core of glacio-lacustrine sediment being gradually deposited by an active layer spring discharging into the basin of an evolving DeKalb mound. Then, during a very advanced stage of the developing DeKalb mound, deposition of the lacustrine core ceased while it was not overlain by any significant amount of water (Flemel et al., 1973, p. 237). This was then followed by the final melting of the remnant, supraglacial, pit-filled ice that inevitably caused deposition of the overlying, smaller satellite mounds (Figure 1) upon a saturated lake bed belonging to the bigger mound (Iannicelli, 2003). This last stage of the sequential events is supported by Parizek $(1969$, p. 96) who described the formation of very similar glacial dead-ice landforms in Canada when he said (verbatim): "A mechanism by which ablational and superglacial debris sloughed off buried stagnant ice onto exposed ground moraine and abandoned lake sediments, adequately accounts for all features observed". Parizek (1969, Figure 5) also illustrated this evolvement with superimposed, small hummocks occurring within the perimeter of the gigantic, circular, ice-contact ridges or rims (or see Iannicelli, 2003, Figure 5). The small hummocks or "doughnut" mounds formed according to Figure 6 (Clayton, 1967; Parizek, 1969; Iannicelli, 2003; Clayton et al., 2008) while c-shaped mounds are "doughnuts" that were breached (Figure 2).

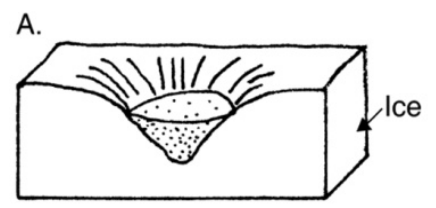

B.

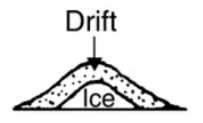

C.

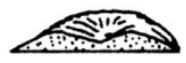

Figure 6. Development of a typical, superimposed "doughnut" mound. Note the two successive inversions in this scheme. Source: Clayton (1967)

Lastly, it's uncertain if the original supraglacial sediment was outwash or till because Flemel et al. (1973) identified the overlying sediment of the mounds only as a deflated lag before the arrival of a loess cap (previously mentioned). The previously discussed New York analogy shows part of its glacio-lacustrine sediment capped by outwash caused by outwash flowing over the stagnant glacial dead ice (Fleisher, 1986). Whether the sediment is outwash or till overlying the DeKalb mounds, it nevertheless, is properly referred to as supraglacial drift in this study just like it was reported in Iannicelli (2003, Figure 7). A bold statement by Curry et al. (2008, p. 149) and Curry et al. (2010, p. 88) such that "thick supraglacial drift was not present during the formation of all DeKalb mounds" is negated by Johnson and Menzies (1996, p. 150) who said "successive ice-marginal positions coincided that resulted in a morainic complex of the superposed type". This is the same area that encompasses the lowland, gigantic, oriented DeKalb mounds.

\subsection{Contact Boundaries}

A dual complaint by Curry et al. (2012) addresses the physical geographic setting plus the type of surface that the mound's lacustrine core lies upon. Curry et al. (2012) stated that the big mounds with their lacustrine cores do not lie within a large, linear trough of the till bed. However, this is just simply untrue because a set of oriented DeKalb mounds such as Figure 2 lies only over a simple ground moraine, all within a till lowland flanked immediately to the south and farther to the north by higher-elevated moraines (Flemal et al., 1973, Figure 1; Lineback, 1979; Iannicelli, 2003, Figure 1) (Figure 4). The second part of the complaint from Curry et al. (2012) 
points out that the lacustrine core lies over an irregular, wavy basal till subsurface but that the generalized flat floor in Iannicelli (2003, Figure 7) (Figure 1) does not mirror this. While this is true, Figure 1 was purposely sketched that way for the reader as a generalized simplification because the contour of the contact between the basal till and basal lacustrine sediment that underlies this particular mound is not actually known. It most probably approaches the contour of the wavy basal till/basal lacustrine sediment contact shown in Figure 3. Subjectively, to this writer's chagrin, a corrigendum of Iannicelli (2003, Figure 2) incorrectly showed a $850 \mathrm{~km}$ horizontal scale bar and this correctively should instead be $850 \mathrm{~m}$ towards measurement of the lowland, gigantic, oriented DeKalb mounds (Figure 7). The pattern of elliptical mounds in both Figure 7 or Figure 2 compares well with Parizek's (1969, Figure 10) illustration of patterned elliptical, multiple, detached ice blocks depositing their own individual circular, ice-contact ridges or rims (Figure 8). This is besides Parizek (1969, Figure 5) also showing these detached ice blocks depositing hummocks ("doughnut" mounds) after melting occurred inside the perimeter of their circular ice-contact ridges (see also Iannicelli, 2003, Figure 5).

\subsection{Isotope Data and Paleontology}

Additional dubious concerns by Curry et al. (2012) about the model (Figure 1) in Iannicelli (2003) relate to: isotope data indicative of the type of water that the lacustrine core formed in; plus organic material found in the lacustrine core. The first part of the challenge in Curry et al. (2012) says that a Kane County, IL, ice-walled lake plain's lacustrine sediment was sourced predominantly from precipitation via an active layer spring (Curry et al., 2008, p. 150; Curry et al., 2010, p. 86), unlike the DeKalb mound in DeKalb County, IL that was sourced from meltwater. However, this point is moot here because even though both types of landforms are somewhat genetically different, they share the common denominator of an active layer spring. Although Flemel et al. (1973) said that spring-fed meteoric water flowed into basin of an evolving DeKalb mound, the deduction here is that there may have been a range of varying amounts of glacial meltwater and meteoric water in the subglacial basin over time. This is because the subglacial lake was surrounded by ice walls and an ice roof of the previously discussed ice cavity. The opposite of that can be said for an evolving ice-walled lake that possessed exterior, sediment-laden ice walls without a glacial ice roof in the adopted model by Curry et al. (2012) (or see this model in Clayton et al., 2008). One final note to this is that very large clasts were absent within the lacustrine core of an evolving lowland, gigantic, oriented DeKalb mound (Flemel et al., 1973). This infers a lack of very large clasts from possible melt-out of the ice roof within the ice cavity. That's because the stagnant ice block was relatively not very thick (Figure 1), which suggests an absence of englacial material in 1 or $2 \mathrm{~m}$ of ice above the ice roof. Above that mark was the supraglacial portion of the ice, which later physically rested upon the completely constructed glacio-lacustrine core as previously discussed. The other doubt by Curry et al. (2012) concerned how organic material would be deposited within the evolving glacio-lacustrine core of sediment if a supraglacial drift cap existed. A search for organic material by Flemel et al. (1973, p. 237) found only spruce pollen within the core of lacustrine sediment from the lowland, gigantic, oriented DeKalb mound. Spruce pollen is a nanoparticle that would have been carried with the suspended grains through the active layer of the surrounding till and then being discharged from a spring and into the subglacial lake of an evolving DeKalb mound. A comparative example is the work of King (1990) who only found pollen in a $800 \mathrm{~m}$ long late Wisconsinan kettle named Chatsworth Bog located near a moraine in Livingston County, IL (Sibley, IL, 7.5' quadrangle). 


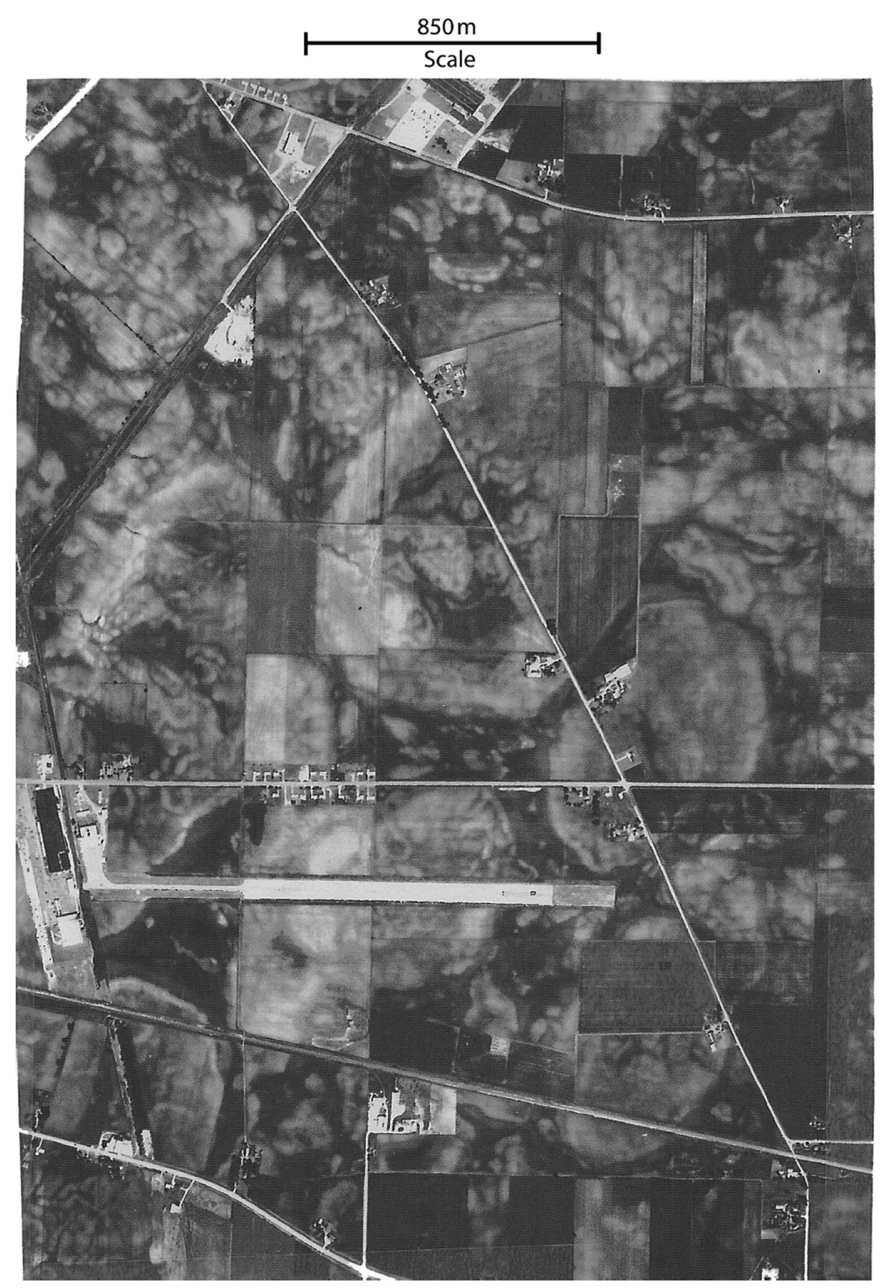

Figure 7. Aerial photograph of lowland, gigantic, oriented DeKalb mounds located just east of DeKalb, IL. North is towards the top. A sketch of this appears in Figure 2. U.S.D.A. aerial photograph \# 3EE-127

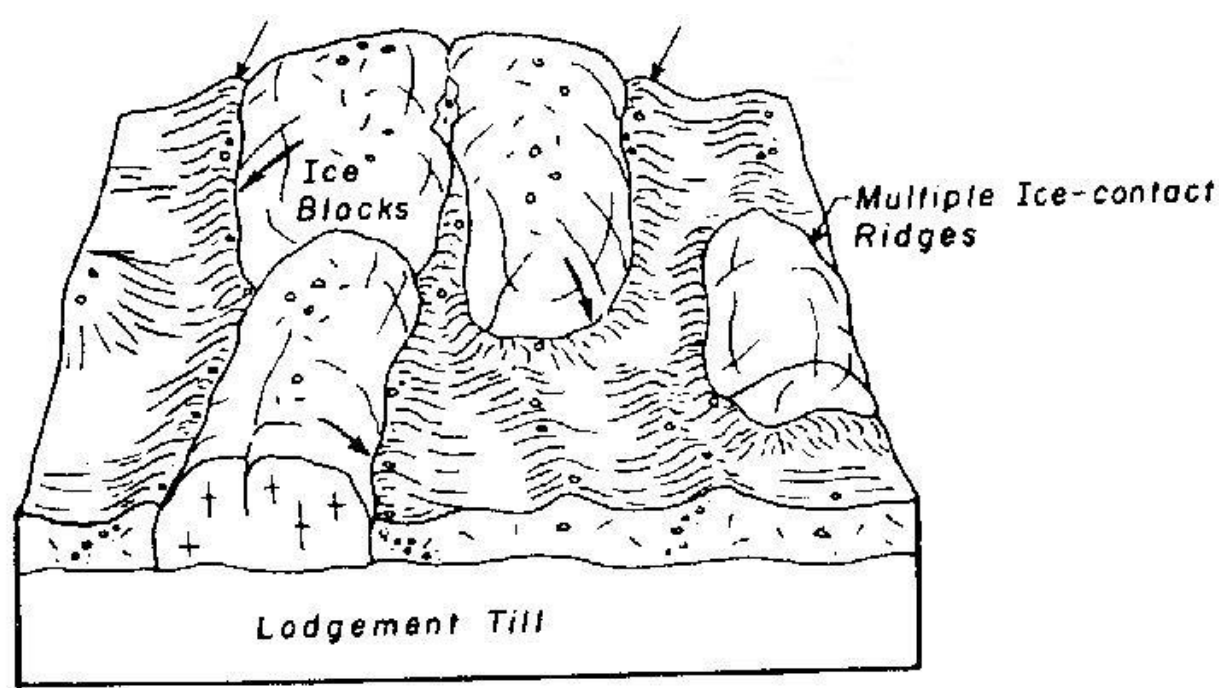

Figure 8. Patterning of elliptical, multiple, detached glacial ice blocks with each one depositing their own circular, ice-contact ridges or rims. This compares well with the patterning of the elliptical DeKalb mounds shown in Figures 2 and 7. Source: Parizek (1969) 


\subsection{Ice Shield Relevancy to Non-Annual Rhythmites}

Lastly, Curry et al. (2012) dispute the model of Iannicelli (2003, Figure 7) (Figure 1) by saying it doesn't allow for sorting of sediment in ultimately constructing a core of lacustrine rhythmical beds as described by Flemel et al. (1973). This doubt is resolved by the previously discussed modification of the detached glacial ice block into a sheltering ice block that acted as a repository for the accumulation of glacio-lacustrine sediment within an evolving lowland, gigantic, oriented, DeKalb mound. While suspended grains are delivered by an active layer spring into the subglacial (paleo)lake, the sheltering ice block would have served as a shield in preventing wind-driven currents. This allowed for the suspended sediment to fall out and settle as thinly laminated silt and clay. Flemel et al. (1973) said the sediment was an expression of varves but that the distinction of seasonal deposition is lacking (non-annual rhythmites). The preceding geomorphic dynamics are substantiated because a coincidental parallel situation of a perennial lake ice-cover ("summer lake ice") help produce a very similar core of lacustrine sediments within a (paleo)glacial ice-walled lake basin influenced by active layer springs (Curry et al., 2008, p. 150; Curry et al., 2010, p. 86), located just outside the study area of Flemel et al. (1973) and Iannicelli (2003). Completing the overall scenario, the rim that runs around the perimeter of a lowland, gigantic, oriented DeKalb mound, flanks and contains the core of glacio-lacustrine sediment. It is composed of pebbly sand (Flemel et al., 1973, p. 237) and it developed due to washed till (Figure 3) sliding over the flanks of a detached ice block that resulted in the enclosing, circular ice-contact ridge (Iannicelli, 2003) (Figures 1 and 8).

\section{Arguing Against an Ice-Walled Lake Hypothesis}

\subsection{Orientation and Morainic Quality}

Pertaining to only the investigated area of Flemel et al. (1973) or Iannicelli (2003), this study voices its own doubts towards an ice-walled lake hypothesis as an origin for the lowland, gigantic, oriented, DeKalb mounds. The most distinguishing characteristic of these big mounds is that they are elliptical in shape while being strikingly parallel to the NE-SW trend of the morainic ridges which are the elevated Tiskilwa Till and Malden Till members (Flemel et al., 1973, p. 234; Iannicelli, 2003, p. 172 and 180) (Figures 2 and 4). This unique quality was one criterion amongst others used by Iannicelli (2003) to conclude that this category of mounds is morainic in origin. The limits of the mound field in either Flemel et al. (1973, Figure 1) or Iannicelli (2003, Figure 1) (Figure 4) in DeKalb County, IL are approximately $8 \mathrm{~km}$ away from the landform in Kane County, IL, identified and discussed by Curry et al. (2008) and Curry et al. (2010) as an ice-walled lake plain. They also referred to this landform as a "DeKalb mound" which may be a misnomer here. Very far from their study area, additional analytical data about relict ice-walled lake plains were collected from on or adjacent to the Woodstock, Tinley, Deerfield and Champaign moraines plus from the Marseilles Morainic System (Curry et al., 2008); and also from the Newton, Gilman, Ransom and West Chicago moraines (Curry et al., 2010). Petras (2010, Figure 1.2) borrowed an illustration from Johnson and Clayton (2005) to generalize the geomorphic conditions for an ice-walled lake plain on an elevated moraine in Illinois (Marseilles Morainic System) which is correlative to similar ice-walled lake plains on elevated moraines in Wisconsin such as ones illustrated by Attig (1993, Figure 13) and Ham \& Attig (1997, Figure 25). Hence, overall differentiation is ascertained here whereas the ice-walled lake plain in Petras (2010) is equated as only a component of the elevated moraine while the lowland, gigantic, oriented, DeKalb mounds themselves are equated as a moraine. Another aspect about the issue of orientation relates to modern glacial ice-walled lakes which are typically found only having random non-oriented shapes (Petras, 2010, Figure 1.10). Allred, Luo and Konen (2011) conjectured that the NE-SW orientation of DeKalb mounds evolved normal (perpendicular) to a (paleo)wind from out of the northwest when the mounds hypothetically existed as ice-walled lakes. However, this idea conflicts with the anticyclonic wind system hovering over the continental ice sheet that generated (paleo)winds from out of the northeast, blowing towards the southwest in the vicinity of Illinois (COHMAP Members, 1988). The COHMAP Members' (1988) wind model is valid because other investigators adopted it (Muhs \& Bettis, 2000; Iannicelli, 2010).

\subsection{Other Differentiae}

Landforms in Lake County, IL were identified as ice-walled lake plains in Curry (2006) and were referred by him as "DeKalb mounds". Although the mounds in Curry (2006), Flemel et al. (1973) and Iannicelli (2003) morphologically resemble a crater that's been filled with sediment, the critical element of a NE-SW orientation to the mounds is lacking in Curry (2006) which may disqualify them as true DeKalb mounds. Skewed identification or misjudgement arises within Curry et al. (2008, Figure 4) when they identified the lowland, gigantic, oriented, DeKalb mounds as ice-walled lake plains. This is deemed here as sort of "mixing apples with oranges". Corroborating this discrepancy, is that the superimposed "doughnuts" and c-shaped mounds seen on the lowland, gigantic, oriented DeKalb mounds (Figures 2 and 7) could not have formed over exposed ice-walled 
lakes which is one reason out of many reasons why Flemel et al. (1973) was adamantly opposed to an ice-walled lake origin for the DeKalb mounds. Photographs always show the ubiquitous, smaller satellite mounds are never found superimposed upon authentic, relict, ice-walled lake plains, but instead, are found only lying adjacent to them (Clayton, 1967; Parizek, 1969; Clayton, et al., 2008). Investigators such as Clayton (1967), Parizek (1969), Iannicelli (2003) and Clayton et al. (2008, p. 239) all argue that the associated, small "doughnut" mounds originated from supraglacial drift trapped in surficial pits on stagnant ice (Figure 6). At the same time, this study does not refute that relict, ice-walled lake plains exist wherever there are lowlands in Illinois. For instance, a vast, amoeba-shaped, ice-walled lake plain measuring over $4.5 \mathrm{~km}$ in size is mapped in Curry (2006). However, the criteria of orientation, shape and size rules against it as a true DeKalb mound.

Another dissimilarity, by their own admission, Curry et al. (2010) said there is a big contrast in heights between ice-walled lake plains of North America to that of the DeKalb mounds because the ice-walled lake plains range from just under $20 \mathrm{~m}$ and up to $50 \mathrm{~m}$ while the lowland, gigantic, oriented DeKalb mounds' greatest relief is only $5 \mathrm{~m}$ (Flemel et al., 1973; Iannicelli, 2003).

It's recommended here that the term "DeKalb mound" be reserved only for the gigantic, oriented mounds within the till lowland mostly just east, west and south of DeKalb, IL. Also, there is no doubt that the general observation of over 500 mounds on the till lowland by Flemel et al. (1973) is an array of unattached, solitary "doughnut" mounds, kettles and ice-walled lake plain mounds besides the gigantic, oriented DeKalb mounds altogether within a polygenetic glacial landscape.

\section{Conclusions}

Reporting very detailed explanations about the mechanics of true DeKalb mound formation while supplementing this with other information relative to the mounds, resolve any misconceivement about them. A significant detail of this report centers on the stagnant ice acting as a shield in preventing wind-driven currents which allowed for the fallout of the laminated fine grains within a repository of the stagnant ice that ultimately built the glacio-lacustrine core influenced by groundwater. This is parallel or concordant with "summer lake ice" that covered another unrelated, relict glacial basin in promoting a very similar core of lacustrine sediment influenced by groundwater (Curry et al., 2008, 2010). An important aspect to always keep in mind, is the fact that the mounds are oriented in the same direction as the nearby, NE-SW elevated moraines. The overall conclusion of this in-depth look at the lowland, gigantic, oriented DeKalb mounds mostly just east, west and south of DeKalb, IL is the same as the conclusion of Iannicelli (2003): that a glacial dead-ice origin is responsible for the morainic nature of the DeKalb mounds. The lowland, gigantic oriented DeKalb mounds mostly just east, west and south of DeKalb, IL (Flemel et al., 1973; Iannicelli, 2003) should not be grouped with genetically different landforms (such as ice-walled lake plains) that either occur on elevated moraines or in till lowlands. It is recommended that the term "DeKalb mounds" be reserved only for the lowland, gigantic, oriented mounds reported by Flemel et al. (1973) or Iannicelli (2003).

Reasons are also given to nullify the counter-hypothesis of an ice-walled lake origin for the lowland, gigantic, oriented, DeKalb mounds such as: the lack of superimposed mounds upon authentic, relict, ice-walled lake plains; the non-oriented shapes of modern, typical ice-walled lakes; and the heights of relict ice-walled lake plains in other parts of North America are exceedingly much greater than the relief of the DeKalb mounds.

\section{Acknowledgements}

I wish to thank Kurt Cuffey for an extensive amount of correspondence and some insight concerning modern glaciers. Peter Wadhams, David J. A. Evans, Nelson Ham and Steve Gorelick gave helpful information. Comments made by one anonymous reviewer improved the manuscript.

\section{References}

Allred, K., Luo, W., \& Konen, M. E. (2011). Elongation analysis from prevailing winds of glacial landforms in northern Illinois. 42nd Lunar and Planetary Science Conference, the Woodlands, Texas.

Attig, J. W. (1993). Pleistocene geology of Taylor County, Wisconsin. Wisconsin Geological and Natural History Survey, Bulletin, 90, 25.

Benn, D. I., \& Evans, D. J. A. (1998). Glaciers and Glaciation. London and New York: Arnold Publications.

Bleuer, N. K. (1974). Distribution and significance of some ice-disintegration features in west-central Indiana. Indiana Geological Survey, Occasional Paper, 8, 11.

Brodzikowski, K., \& van Loon, A. J. (1991). Glacigenic Sediments. Developments in Sedimentology 49. Amsterdam and New York: Elsevier Science Publications. 
Clayton, L. (1967). Stagnant-glacial features of the Missouri Coteau in North Dakota. In L. Clayton \& T. F. Freers (Eds.), Glacial geology of the Missouri Couteau and adjacent areas (pp. 25-46). North Dakota Geological Survey, Miscellaneous Series 30.

Clayton, L., \& Moran, S. R. (1974). A glacial process - form model. In D. R. Coates (Ed.), Glacial Geomorphology (pp. 89-119). Binghamton: State University of New York.

Clayton, L., Attig, J. W., Ham, N. R., Johnson, M. D., Jennings, C. E., \& Syverson, K. M. (2008). Ice-walled lake plains: implications for the origin of hummocky glacial topography in middle North America. Geomorphology, 97, 237-248. http://dx.doi.org/10.1016/j.geomorph.2007.02.045

COHMAP Members. (1988). Climatic changes of the last 18,000 years: observations and model simulations. Science, 241, 1043-1052. http://dx.doi.org/10.1126/science.241.4869.1043

Cuffey, K. (2012). [personal communication]. University of California at Berkeley, Dept. of Geography, Berkeley, CA 94720.

Cuffey, K., \& Paterson, W. S. B. (2010). The Physics of Glaciers. N.Y. and UK: Butterworth-Heinemann.

Curry, B. B. (2006). Subtle ice-walled lake terraces identified and mapped with shaded-relief maps of 2-foot DEMS from aerial photography or LIDAR. Geological Society of America, Abstracts with Progams, 38(7), 164.

Curry, B. B., Konen, M. E., \& Larson, T. H. (2008). Stop 7: DeKalb mounds. In B. B. Curry (Ed.), Deglacial history and paleoenvironments of northeastern Illinois (pp. 138-151). Illinois Geological Survey, Open File 2008-1.

Curry, B. B., Konen, M. E., Larson, T. H., Yansa, C. H., Hackley, K. C., Alexanderson, H., \& Lowell, T. V. (2010). The DeKalb mounds of northeastern Illinois as archives of deglacial history and postglacial environments. Quaternary Research, 74, 82-90. http://dx.doi.org/10.1016/j.yqres.2010.04.009

Curry, B. B., Konen, M. E., Larson, T. H., Yansa, C. H., Hackley, K. C., Lowell, T. V., \& Petras, J. (2012). Reply to Letter to the Editor. Quaternary Research, 77. http://dx.doi.org/10.1016/j.yqres.2011.11.010

Fleischer, P. J. (1986). Dead-ice sinks and moats: environments of stagnant ice deposition. Geology, 14, 39-42. http://dx.doi.org/10.1130/0091-7613(1986)14<39:DSAMEO>2.0.CO;2

Flemal, R. C., Hinkley, K. C., \& Hesler, J. L. (1973). DeKalb mounds: a possible Pleistocene (Woodfordian) pingo field in north-central Illinois. In R. F. Black, R. P. Goldthwait, \& H. B. Willman (Eds.), The Wisconsinan Stage (pp. 229-250). Geological Society of America, Memoir, 136.

Ham, N. R., \& Attig, J. R. (1997). Pleistocene geology of Lincoln County,Wisconsin. Wisconsin Geological and Natural History Survey, Bulletin, 93, 32.

Iannicelli, M. (2003). Reinterpretation of the original DeKalb mounds in Illinois. Physical Geography, 24, 170-182. http://dx.doi.org/10.2747/0272-3646.24.2.170

Iannicelli, M. (2010). Evolution of the Driftless Area and contiguous regions of midwestern USA through Pleistocene periglacial processes. The Open Geology Journal 4, 35-54. http://dx.doi.org/10.2174/1874262901004010035

Iannicelli, M. (2012). Letter to the Editor. Quaternary Research, 77. http://dx.doi.org/10.1016/j.yqres.2011.09.012

Johnson, M. D., \& Clayton, L. (2005). Supraglacial landsystem in lowland terrain. In D. J. A. Evans (Ed.), Glacial Landsystems (pp. 228-259). Oxford, UK: Hodder, Arnold Publications.

Johnson, W. H., \& Menzies, J. (1996). Supraglacial and ice-marginal deposits and landforms. In J. Menzies (Ed.), Past Glacial Environments, (pp. 137-160). N.Y. and UK: Butterworth-Heinemann.

King, J. E. (1990). Stop 10: Chatsworth Bog: a Woodfordian kettle. In L. R. Follmer, D. P. McKenna, \& J. E. King (Eds.), Quaternary records of Central and Northern Illinois (pp. 71-75). American Quaternary Association, 9th Biennial Meeting, Guidebook 20.

Lineback, J. (1979). Quaternary deposits of Illinois. Illinois Geological Survey, map scale: 1:500,000.

Menzies, J., \& Shilts, W. W. (1996). Subglacial environments. In J. Menzies (Ed.), Past Glacial Environments (pp. 15-136). UK: Butterworth-Heinemann.

Miall, A. D. (1977). A review of the braided river depositional environment. Earth Science Reviews, 13, 1-62. http://dx.doi.org/10.1016/0012-8252(77)90055-1 
Mickelson, D. M., Clayton, L., Fullerton, D. S., \& Borns, H. W. Jr. (1983). The late Wiconsinan Glacial record of the Laurentide ice sheet in the United States. In H. E. Wright (Ed.), Late Quaternary Environments of the United States (pp. 157-189). Minesota: University of Minnesota Press.

Muhs, D. R., \& Bettis, E. A. (2000). Geochemical variations in Peoria Loess of western Iowa indicate paleowinds of midcontinental North America during last glaciations. Quaternary Research, 53, 49-61. http://dx.doi.org/10.1006/qres.1999.2090

Parizek, R. R. (1969). Glacial ice-contact ridges and rings. Geological Society of America Special Paper, 123, 49-102.

Petras, J. (2010). Genesis and sedimentation of an ice-walled lake plain in northeastern Illinois. M. Sc. thesis. University of Illinois at Urbana-Champaign. 